\title{
IMPACT OF MACROECONOMIC AND ENDOGENOUS FACTORS ON NON PERFORMING BANK ASSETS
}

\author{
Vighneswara Swamy \\ Indian Business School, Hyderabad, India
}

\begin{abstract}
Determinants of default risk of banks in emerging economies have so far received inadequate attention in the literature. Using panel data techniques, this paper seeks to examine the impact of macroeconomic and endogenous factors on non-performing assets during 1997-2009. The findings reveal some interesting inferences contrary to the perception of few opinion makers. Lending rates have been found to be not so significant in affecting the non-performing loans, which is contrary to the general perception. Such assets have a negative and significant influence, indicating that large banks may have better risk management procedures and technology which definitely allows them to finish up with lower levels of non-performing assets compared to smaller banks. Further, this study suggests that private banks and foreign banks have advantages in terms of their efficiencies in better credit management that contains non-performing assets. That indicates that bank privatization can lead to better management of default risk.
\end{abstract}

Key Words: Banks, Risk management, Ownership structure, Financial markets, Non-Performing assets, Lending policy, Macro-economy, Central banks

JEL Classification: G21, G32, E44, E51

\section{Introduction}

Global financial crisis, which has developed into the most severe crisis of the post-World War II crisis, has hit the real economy on a devastating scale resulting in the collapse of financial markets and institutions. Moreover, output per capita is projected to slide down in countries representing three-quarters of the global economy. The consequent deterioration in the economic environment has led to a rise in the overall level of stress in the banking sectors. Commercial bank loan charge-offs in the US and Europe may exceed the levels reached during the 1991-1992 recession, even though they should remain below the levels experienced in the US during the Great Depression. 
On a thorough analysis of the crisis, financial stability has once again emerged as an important area of concern in the financial systems across the globe. Financial stability is widely accepted as a situation in which financial system is capable of satisfactorily performing its three key functions simultaneously: (1) efficient and smooth facilitation of the inter-temporal allocation of resources from the surplus economic units to the deficit economic units; (2) managing the forward looking financial risks with appropriate pricing; and (3) to be prepared all the time to absorb the financial and real economic surprises and shocks. The core function of the payment system should therefore not fail as well.

Counterparty risk, being an important risk in the financial system more particularly of the banking system, poses a bigger challenge in order to achieve financial stability. Counter-party risk is an outcome directly related to the Non-Performing Assets ${ }^{1}$ [NPAs] of a financial institution. Even though NPAs are permanent phenomenon in the balance sheets of the financial institutions, if not contained properly, they eventually lead to crisis that can pose big threats of contagion that can engulf the financial health of the system. The problem of NPAs in the financial sector has been an matter of concern for all economies and resolution of NPAs has become synonymous to functional efficiency of financial intermediaries.

As per the Global Financial Stability Report of International Monetary Fund, (IMF, 2009), identifying and dealing with distressed assets, and recapitalizing weak but viable institutions and resolving failed institutions are stated as the two of the three important priorities which directly relate to NPAs. In view of this, it is essential to identify and understand the determinants of NPAs, which is the motive for this paper.

This paper is organised into four sections. The next section is a very brief overview of the theoretical considerations along with a short review of latest literature. In section 3 discussion on factors relevant for NPAs is presented. In section 4, the reader will find an attempt to model this research on NPAs in an economy. The results are presented in section 5 showing possible impact of macroeconomic and endogenous determinants on NPAs. Policy issues and conclusions follow in the following sections.

\footnotetext{
${ }^{1}$ Loans the bank anticipates will have difficulty in recovering. NPAs mainly arise due to the default of the borrower which involves his inability or unwillingness in meeting the commitments to the loan. Non-performing assets (NPAs) or bad loans, as they are commonly called, have been a menace for the banking sector across the world.
} 


\section{Theoretical Considerations}

The critical role of financial and banking development in economic growth in any economy has been established by many researchers (Levine, 2004 and Singh, 2005). Goldsmith (1969 ) is adamant in pointing to excessive credit growth as the harbinger of all crises. The role of how financial crisis could destabilise that role is described in Ariff (2012). These pointers should be judged against the state of affairs that there is as yet a credible theory of financial market equilibrium (Allan and Gale, 2007).

In the process of providing credit assistance to the investment activities and projects in the economy, financial institutions face inherent risks in the form of default risk which results in build-up of Non-Performing Assets (NPAs) that have a negative effect on the profitability of the financial institutions. Typically a credit transaction involves a contract between two parties: the borrower and the creditor (bank) are subject to a mutual agreement on the 'terms of credit'. ${ }^{2}$ Optimising decision pertaining to the terms of credit could differ from the borrower to that of the creditor. As such, the mutual agreement between the borrower and the creditor may not necessarily imply an optimal configuration for both. The most important reason for default ${ }^{3}$ could be mismatch between borrower's terms of credit and creditor's terms of credit. However, a common perspective is that both the cases of defaulter and nonperformer imply similar financial implications, that is, financial loss to banks. Moreover, regulatory and supervisory process does not focus on such a distinction between defaulter and non-performer as far as prudential norms are concerned.

A synoptic look at the available literature conveys some useful insights into the determining factors of NPAs across countries. Quite a lot of economies have experienced such distressed debt cycles. NPA levels and capital to risk (weighted) assets ratio (CRAR) of developing and advanced countries presented in Table 1 and the provisions to NPAs and return on assets (ROA) of developing and advanced countries captured in Table 2 explain the differences in the levels as well as the approaches towards NPA management in different countries.

\footnotetext{
${ }^{2}$ The 'terms of credit' are defined over five critical parameters, viz, amount of credit, interest rate, maturity of loans, frequency of loan servicing and collateral.

${ }^{3}$ A 'default' entails violation of the loan contract or the agreed terms of the contract, while a non-performing loan entails that the borrower does not renege from the loan contract but fails to comply the repayment schedule due to evolving unfavourable conditions.
} 
Table 1: NPA levels and CRAR of Developing \& Advanced Countries

\begin{tabular}{|l|c|c|c|c|c|c|c|c|c|}
\hline \multicolumn{1}{|c|}{ Country } & \multicolumn{7}{c|}{ DRAR } & \multicolumn{7}{c|}{ NPA/TL } \\
\hline & $\mathbf{2 0 0 2}$ & $\mathbf{2 0 0 6}$ & $\mathbf{2 0 0 7}$ & $\mathbf{2 0 0 8}$ & $\mathbf{2 0 0 2}$ & $\mathbf{2 0 0 6}$ & $\mathbf{2 0 0 7}$ & $\mathbf{2 0 0 8}$ \\
\hline \multicolumn{8}{|c|}{ Developing Economies } \\
\hline China & - & - & 8.4 & 8.2 & 26 & 7.5 & 6.7 & 2.5 \\
\hline India & 12 & 12.4 & 12.3 & 13 & 10.4 & 3.5 & 2.5 & 2.3 \\
\hline Indonesia & 20.1 & 21.3 & 19.3 & 16.8 & 24 & 13.1 & 4.1 & 3.5 \\
\hline Korea & 11.2 & 12.8 & 12.3 & 10.9 & 2.4 & 0.8 & 0.7 & 1.1 \\
\hline South Africa & 12.6 & 12.3 & 12.8 & 12.5 & 2.8 & 1.2 & 1.4 & 2.6 \\
\hline \multicolumn{7}{|c|}{ Advanced Economies } \\
\hline Australia & 9.6 & 10.4 & 10.2 & 10.9 & 0.4 & 0.2 & 0.2 & 0.5 \\
\hline Canada & 12.4 & 12.5 & 12.1 & 12.7 & 1.6 & 0.4 & 0.7 & 1.1 \\
\hline France & 11.5 & - & 10.1 & - & 4.2 & 3.2 & 2.7 & - \\
\hline Germany & 12.7 & - & 12.9 & - & 5 & 4 & 2.7 & - \\
\hline Italy & 11.2 & 10.7 & 10.4 & - & 6.5 & 5.3 & 4.6 & - \\
\hline Japan & 9.4 & 13.1 & 12.9 & 12.3 & 7.4 & 2.5 & 1.5 & 1.5 \\
\hline $\begin{array}{l}\text { United } \\
\text { Kingdom }\end{array}$ & 13.1 & 12.9 & 12.6 & - & 2.6 & 0.9 & 0.9 & - \\
\hline United States & 13 & 13 & 12.8 & 12.5 & 1.4 & 0.8 & 1.4 & 2.3 \\
\hline Soure: Global Fing
\end{tabular}

Source: Global Financial Stability Report, April 2009, IMF

Table 2: Provisions to NPAs and ROA of Developing \& Advanced Countries

\begin{tabular}{|c|c|c|c|c|c|c|c|c|}
\hline \multirow[t]{2}{*}{ Country } & \multicolumn{4}{|c|}{ PROVISIONS TO NPAs } & \multicolumn{4}{|c|}{ ROA } \\
\hline & 2002 & 2006 & 2007 & 2008 & 2002 & 2006 & 2007 & 2008 \\
\hline \multicolumn{9}{|c|}{ Developing Economies } \\
\hline China & - & - & 39.2 & 115.3 & - & 0.9 & 1 & - \\
\hline India & - & 58.9 & 56.1 & 52.6 & 0.8 & 0.9 & 0.9 & 1 \\
\hline Indonesia & 130 & 99.7 & 87.7 & 98.5 & 1.4 & 2.6 & 2.8 & 2.6 \\
\hline Korea & 89.6 & 175.2 & 199.1 & 155.4 & 0.6 & 1.1 & 1.1 & - \\
\hline South Africa & 46 & - & - & - & 0.4 & 1.4 & 1.4 & 1.8 \\
\hline \multicolumn{9}{|c|}{ Advanced Economies } \\
\hline Australia & 106.2 & 204.5 & 183.7 & 87.2 & 1.4 & - & 1 & 0.9 \\
\hline Canada & 41.1 & 55.3 & 42.1 & 34.7 & 0.4 & 1 & 0.9 & 1.3 \\
\hline France & 58.4 & 58.7 & 61.4 & - & 0.5 & - & 0.4 & - \\
\hline Germany & - & - & 77.3 & - & 0.1 & 0.5 & 0.2 & - \\
\hline Italy & - & 46 & 49.5 & - & 0.5 & 0.8 & 0.8 & - \\
\hline Japan & - & 30.3 & 26.4 & 24.9 & -0.7 & 0.4 & 0.2 & 0.3 \\
\hline $\begin{array}{l}\text { United } \\
\text { Kingdom }\end{array}$ & 75 & - & - & - & 0.4 & 0.5 & 0.4 & - \\
\hline United States & 123.7 & 137.2 & 93.1 & 84.7 & 1.3 & 1.3 & 0.8 & 0.3 \\
\hline
\end{tabular}

Source: Global Financial Stability Report, April 2009, IMF.

Bank Regulation based CRAR of select countries is captured in Table 3 and Figure 1. In the USA, the non- and sub-performing loans resolution was embedded into the savings and loans crisis from 1989 to 1994. In Japan, the NPA cycle began in 1997 and in China and the 
Figure 3: Comparison of Gross Domestic Product to Bank Credit in India

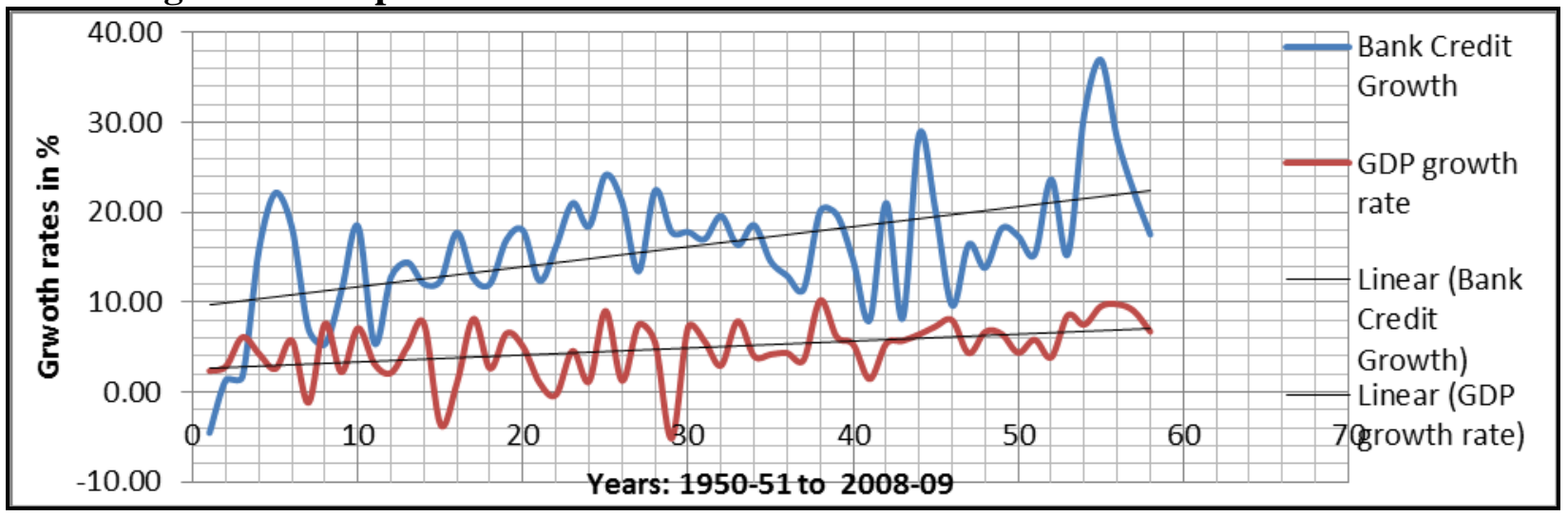

Source: Compiled by Author based on data from Reserve Bank of India publications

rest of Asia deal with NPAs sub-prime loans (SPLs) since 1999. The origin of the Chinese NPAs crisis can be traced to political issues. During the centrally planned economy from 1949 onwards, loans were granted by state owned banks to state-owned companies without proper credit due diligence at predetermined standardised conditions by the government. Especially, in the overheated economy of the 1990s domestic credits extended enormously and grew by 30 percent year on year between 1992 and 1995 (Chen, 2004; Sprayregen et al., 2004).

Table -3: Bank Regulatory Capital to Risk-Weighted Assets [in percent]

\begin{tabular}{|c|c|c|c|c|c|c|c|}
\hline No. & Country & 2002 & 2003 & 2004 & 2005 & 2006 & 2007 \\
\hline 1 & China & -5.9 & -4.7 & 2.5 & 4.9 & 8.4 & 8.2 \\
\hline 2 & Hong Kong SAR & 15.3 & 15.4 & 14.9 & 15.2 & 13.4 & 14.3 \\
\hline 3 & India & 12.7 & 12.9 & 12.8 & 12.3 & 12.3 & 13 \\
\hline 4 & Indonesia & 22.3 & 19.4 & 19.3 & 21.3 & 19.3 & 16.8 \\
\hline 5 & Korea & 11.1 & 12.1 & 13 & 12.8 & 12.3 & 10.9 \\
\hline 6 & Brazil & 16.6 & 18.8 & 18.6 & 17.9 & 18.9 & 18.4 \\
\hline 7 & Russia & 19.1 & 19.1 & 17 & 16 & 14.9 & 16.8 \\
\hline 8 & France & 11.5 & 11.9 & 11.5 & 11.4 & 10.9 & $\cdots$ \\
\hline 9 & Germany & 12.7 & 13.4 & 13.2 & 12.2 & 12.5 & $\ldots$ \\
\hline 10 & South Africa & 12.6 & 12.4 & 14 & 12.7 & 12.3 & 12.2 \\
\hline 11 & Australia & 9.6 & 10 & 10.4 & 10.4 & 10.4 & 10.3 \\
\hline 12 & Canada & 12.4 & 13.4 & 13.3 & 12.9 & 12.5 & 12.1 \\
\hline 13 & Japan & 9.4 & 11.1 & 11.6 & 12.2 & 13.1 & 12.9 \\
\hline 14 & United States & 13 & 13 & 13.2 & 12.9 & 13 & 12.8 \\
\hline 15 & United Kingdom & 13.1 & 13 & 12.7 & 12.8 & 12.9 & $\ldots$ \\
\hline
\end{tabular}

Source: Global Financial Stability Report, April 2009, IMF. 
Figure 1: Bank Regulatory Capital to Risk-Weighted Assets

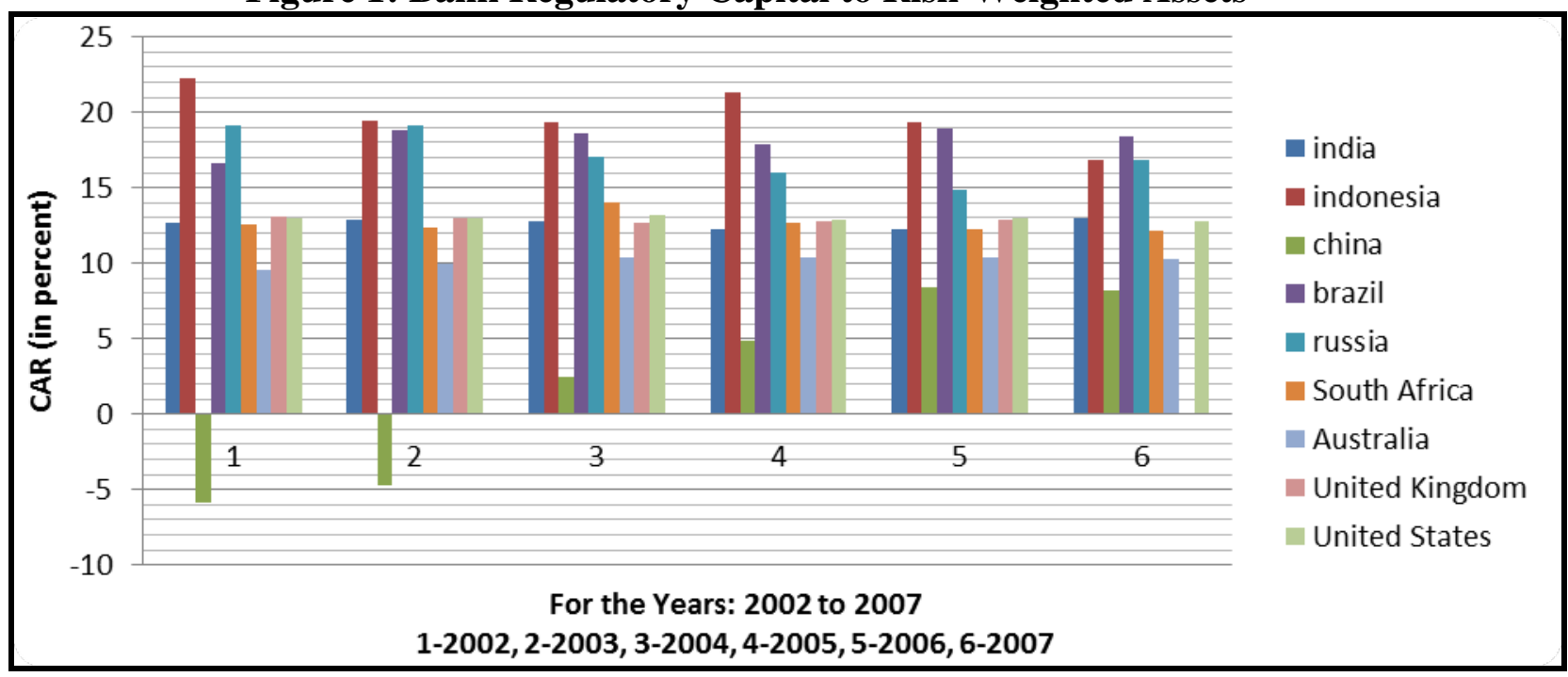

Source: Global Financial Stability Report, April 2009, IMF.

A typically high leverage in the country shown by a Debt/Gross Domestic Product (GDP) ratio of 146 percent may be an indicator for the problem of NPAs (see Ernst \& Young, 2001). High leverage was experienced in the real estate sector, particularly during the rise of the Japanese real estate bubble in the 1980s. With the burst of the bubble in the 1991 and the dramatic economic slowdown, real estate values waned tremendously in the case of Japan. As an aftermath, borrowers defaulted on the debt service and lenders had to sign big losses. Lacking regulations and tax incentives by the Japanese Government as well as insufficient equity reserves of the banks to compensate write-offs of distressed debt, banks tried to deal with the problem by a wait-and-see approach. Barseghyan (2004) identifies a link between the Japanese government's reluctance to solve the bad loan problem and the economic slowdown. He opines that the Governments behaviour deteriorated the economic situation of Japan and affirms this hypothesis by a normative study.

In the case of Thailand, the causes for NPAs include factors like liberalized capital and current account, a legal system that made credit recovery time consuming and difficult, real estate speculations, steep rise in interest rates and inability of the banks to assess the credit risk. To overcome the problem the Financial Sector Restructuring Plan (1998) focused on capital support facilities for bank recapitalization and setting up of Asset Management Corporations (Devakula, Pridiyathorn, 2001). Korean causes for distressed loans were like directed credit (Kang, Moon-Soo, 2001), the “compressed growth policy” which backfired when slowing demand and rising input costs placed severe stress on their profitability, their 
lack of monitoring and contagion effects. These issues were attempted to be countered with measures like; creation of the Korea Asset Management Corporation (KAMCO) and a NPA fund to support the acquisition of NPAs (Bama, 2002) and Corporate Restructuring Vehicles (CRVs) and Debt/Equity Swaps were made use of to ease the resolution of bad loans.

Indian banking system has endured the stress of global financial crisis as revealed in the advancement in the Capital to Risk-Weighted Assets Ratio (CRAR). On the whole CRAR of all (81) Scheduled Commercial Banks (SCBs) improved to 13.2 per cent at end-March 2009, continuing to be considerably well above the required minimum of 9.0 per cent. The gross NPAs to gross advances ratio (GNPA) continued to be at 2.3 per cent as at end-March 2009 as it was at end-March 2008. The ROA also remained unchanged at 1.0 per cent at endMarch 2009 over its level at end-March 2008 indicating no deterioration in efficiency with which banks deployed their assets. The Return on Equity (ROE) improved from 12.5 per cent at end-March 2008 to 13.3 per cent as at end-March 2009, signifying increased efficiency in the capital usage by banks. In India, as in most other countries, NPAs are only an indicator of loan performance.

Figure 2: GNPA levels of Bank Groups in India

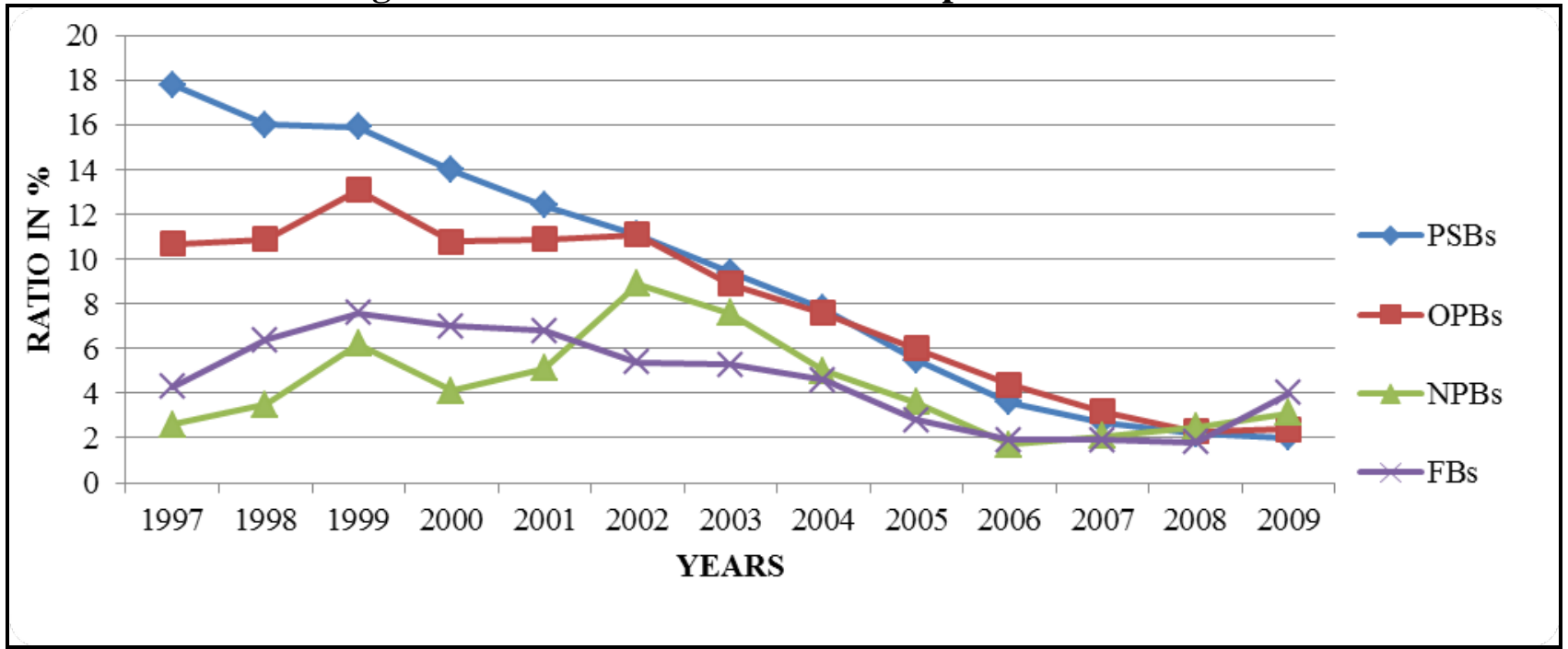

Source: Compiled by Author based on data from Reserve Bank of India publications.

The degree to which it measures actual performance of banks depends on the quality of accounting, auditing, regulation and supervision and the amount of 'ever greening' of weak loans, through restructuring, which is an incessant problem in India to judge from the numerous circulars against the practice, which the Reserve Bank of India (RBI) has issued against it over the last decade. Although NPAs have been substantially reduced since regulation was tightened in 1993, especially in the Public Sector Banks (PSBs), the 
momentum has recently slowed down and the levels of NPAs remain high compared to international standards (refer o Figure-2). He further argues that the problems of NPAs have a sizeable overhang component, resulting from infirmities in the prevailing practices of debt recovery, inadequate legal provisions for foreclosure and bankruptcy and hitches in the execution of court decrees. The problem is exacerbated by the regulatory provisions for loan classification vis-à-vis international best practices.

Even though public sector banks have recorded surges in profitability, efficiency in asset quality and intermediation costs in the 1990s, they continue to linger with high interest rate spreads astonishingly with lower rates of return, and higher operating costs. In an advancing rate regime, prime borrowers would switch over to other possibilities such as capital markets, internal accruals, etc., for their fund requirements. Under such conditions, banks would have no alternative but to mitigate the quality of borrowers which increase the probability of generation of NPAs (Bhattacharya, 2001).

\section{Factors Relevant for NPAs}

\subsection{Macroeconomic Factors}

Most of the empirical evidence suggests that banks' NPAs as closely linked to the economic activity. In other words, macroeconomic factors matter: downturns/slowdowns in the economy, recessions, low rate of savings, weak markets, depressions in industrial production, reduction in per capita income levels and most importantly the inflation levels in the economy. A fair amount of the academic literature has dealt with determinants of banking crisis, which is the most severe of the consequences of bad loans in a banking system which is of valuable understanding as a backdrop for the study of NPAs. ${ }^{4}$

Dermiguc-Kunt and Detragiache (2000) employed a Multivariate Logit Framework to develop an early warning system for banking crisis and a ratings system for bank fragility. Beck, Demirguc-Kunt, and Levine (2005) examined the inter-linkage between bank concentration and banking system fragility where they have established that higher bank concentration is associated with lower profitability. Lis, et.al.,(2000) have found that Gross

\footnotetext{
${ }^{4}$ Non-performing assets is used interchangeably with non-performing loans in this Comment. NPAs are measured on either gross basis or on net basis (net of provisions). While the gross NPAs reflects the quality of loans made by the banks, net NPAs shows the actual burden of the banks.
} 
Domestic Product growth, bank size and Capital had negative effect on NPAs while Loan growth, collateral, net interest margin, debt-equity, market power and regulation regime had a positive impact on NPAs.

Resti and Sironi (2001) examined corporate bond recovery rate referring to bond default rate, macroeconomic variables such as GDP and growth rate, amount of bonds outstanding, amount of default, return on default bonds, and stock return wherein it was established that default rate, amount of bonds, default bonds, and economic recession had negative effect, while the GDP growth rate, and stock return had positive effect on corporate recovery rate. Lis et.al.,(2000) used a simultaneous equation model in which they explained bank loan losses in Spain using a host of indicators, which included GDP growth rate, debt-equity ratios of firms, regulation regime, loan growth, bank branch growth rates, bank size (assets over total size), collateral loans, net interest margin, capital-asset ratio (CAR) and market power of default companies. They found that GDP growth (contemporaneous, as well as one period lag term), bank size, and CAR, had negative effect while loan growth, collateral, net-interest margin, debt-equity, market power, regulation regime and lagged dependent variable had positive effect on problem loans. Sergio (1996) in a study of non-performing loans in Italy found evidence that, an increase in the riskiness of loan assets is rooted in a bank's lending policy adducing to relatively unselective and inadequate assessment of sectoral prospects. Interestingly, this study refuted that business cycle could be a primary reason for banks' NPAs. The study emphasised that increase in bad debts as a consequence of recession alone is not empirically demonstrated. However, according to Bloem and Gorter (2001) NPAs may be caused by wrong economic decision or by plain bad luck.

There are many internal and external factors affecting NPAs in India. While the internal factors might be taking up new projects, promoting associate concerns, business failure, cost overruns during the project implementation stage, strained labour relations, inefficient management, technology related problems, product obsolescence etc., the external factors include GDP growth, default in other countries, high inflation, accidents and natural calamities. Further, it is observed that while there is a positive correlation between the factors such as GDP growth induce the bank credit. Procyclicality is observed in the case of comparison of GDP growth to NPA levels (Figure-3 and Figure-4). Das and Ghosh (2003) established relationship between nonperforming loans of India's public sector banks in terms of various indicators such as; asset size, credit growth and macroeconomic condition and operating efficiency indicators. 
Bercoff, Giovanniz and Grimardx (2002) in their study of Argentinean banks tried to measure NPAs by using the various bank related parameters as well as macroeconomic parameters. Bank specific parameters in their study were Ratio of Networth to Net Assets, Bank's exposure to peso loans, and type of banks such as foreign, private or public. Macroeconomic factors in this study were credit growth, reserves adequacy, foreign interest rate and monetary expansion. They have established that variables such as operating cost, exposure to peso loans, credit growth, and foreign interest rate had a negative effect on NPAs. The macroeconomic variables such as money multiplier and reserve adequacy had a positive impact on NPAs.

Figure 4: Pro-cyclicality of NPAs, Comparison of Gross Domestic Product to Gross NPA Level - Indian Banking

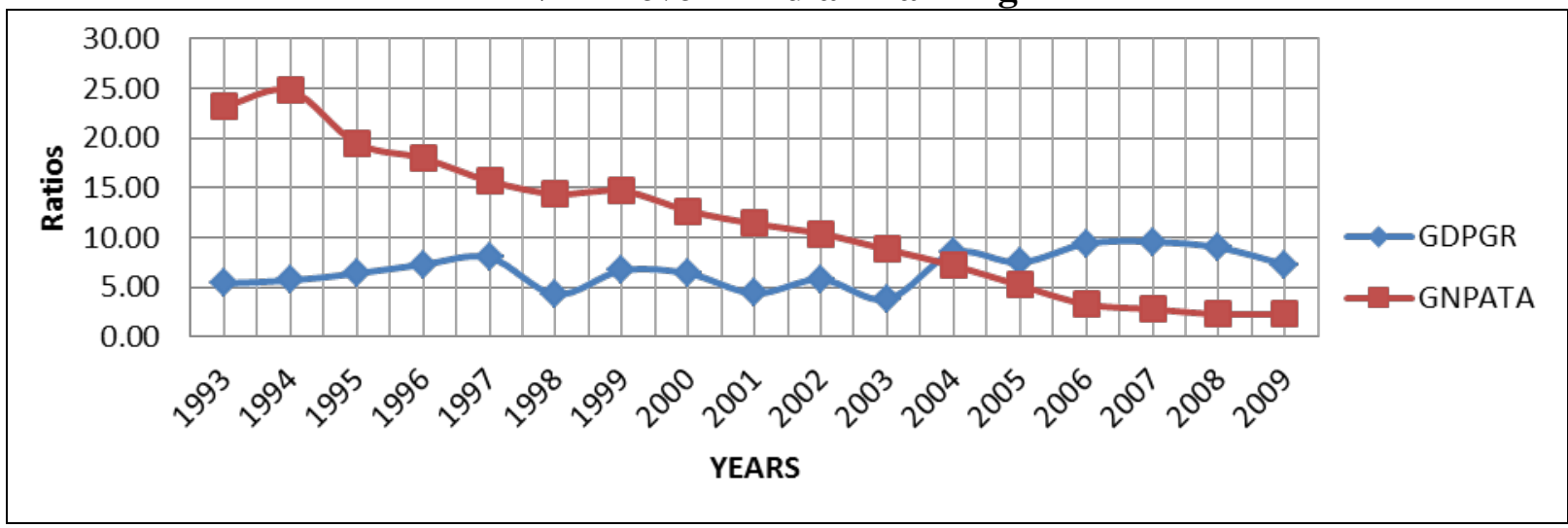

Source: Compiled by Author based on data from Reserve Bank of India publications.

Chen et al. (1998) study the relationship between the risks and the ownership structure, and it appears that a negative correlation exists between the managers' shareholdings and the risks faced by the financial institution. That means that if the managers' shareholding percentage increases, the financial institution will reduce its own risk behaviour. While Berger and De Young (1995) mention that a management team with poor operating capability is unable to correctly appraise the value of collateral, which means that it is difficult for it to follow up on its supervision of the borrower, its poor credit-rating technology will result in management being unable to control and supervise the operating expenses efficiently, thus leading to a significant increase in NPLs. Wahlen (1994) also points out that unexpected changes in the NPL Ratio may indicate that expected future loan losses are relatively nondiscretionary and negatively related to bank stock returns. Therefore, we have considered the various bank groups in Indian Banking based on their ownership structures for the analysis. 
Ownership pattern can also affect the bad loan levels significantly. In times of downturn the government would often turn to banks for financial resources through policy loans for the State Owned Enterprises (SOEs). Projects financed by these policy loans gave rise to growing default rates (Huang, 1999). The biased lending behaviour of the banks to SOEs is supported by other research findings as well (Lu et al., 2001). In case of Taiwanese banks the rate of non-performing loans decreases as the government shareholding in bank goes higher up to 63.51 per cent, while thereafter it increases (Hu et al., 2002). Few studies have also indicated a relationship between the size of the bank and the level of bad loans. Bank's sizes are often found negatively related to the rate of non-performing loan (Hu et al., 2002). Bodla and Verma (2006) have emphasised that financial sector reforms have brought in greater competition among the banks and have brought their profitability under pressure.

Accordingly, banks face a number of challenges such as; worrying level of NPAs, stringent prudential norms, increasing competition, growing customer expectations, increasing pressure on profitability, liquidity and credit risk management, assets-liability management, shrinking size of spread, rising operating expenditure and so on. However, Singh (2005) argues that globalization of operations and new technologies development are taking place swiftly and these has given rise to the increase in resource productivity, increasing level of profitability, deposits and credits and thereby decrease in NPAs.

\subsection{Endogenous Factors}

The literature on these issues identifies determinants of banks risk taking that can be translated into a tractable empirical specification by measuring the effect of observable variables like; capital adequacy, credit growth, operational efficiency, branch spread and others. Rajaraman, Bhaumik and Bhatia (1999) have explained the variations in NPAs across the Indian banks through differences in operating efficiency, solvency and regional concentration. Again Rajaraman and Vasishstha (2002) in their empirical study have proved that significant bivariate relationship exists between NPAs of the public sector banks and the inefficiency problems. Das (1999) has contrasted the different efficiency measures of public sector banks by applying data envelopment analysis model and concluded that the level of NPAs has significant negative relationship with efficiency parameters.

Kwan and Eisenbis (1997) have examined the relationship between problem loans and bank efficiency by employing Granger-causality technique and found that high level of problem loans cause banks to increase spending on monitoring working out and / or selling 
off these loans and possibly become more diligent in administering the portion of their existing loan portfolio that is currently performing. Ranjan and Dhal (2003) attempted an empirical analysis of the NPAs of Public Sector banks in India and probed the response of NPAs to terms of credit, bank size, and macroeconomic condition and found that terms of credit have significant effect on the banks' Non Performing Assets in the presence of bank size and macroeconomic shocks. They also found that alternative measures of bank size could give rise to differential impact on NPAs.

\section{Empirical Specification and Estimation}

In this section, we introduce the methodology adopted for the empirical analysis. The objective here is to identify the determinants of NPAs in Indian Banking. Accordingly, there is a need to estimate a relationship of the following form using the panel data consisting of different groups of banks in Indian Banking industry (such as State Bank Group, Nationalised Banks, Old Private Banks, New Private Banks and Foreign Banks) data across a period from 1997 to 2009.

The equation can be;

$$
\text { NPAit }=\alpha+\beta \mathrm{X}_{\mathrm{it}}+\epsilon_{\mathrm{it}}----------------->
$$

Where, $\alpha$ represents the intercept, $\beta_{1, \ldots \ldots} \ldots B_{n}$ represent the respective regression coefficients for explanatory variables $X_{1} \ldots \ldots X_{n}$. For estimating the determinants of NPA, the equation can be;

$$
\mathrm{NPA}_{\mathrm{it}}=f\left[\mathrm{ME}_{\mathrm{t}} \mathrm{E}_{\mathrm{it}}\right]
$$

Where, $\mathrm{ME}_{\mathrm{t}}$ represent the Macro-Economic Variables and $\mathrm{E}_{\mathrm{it}}$ represent the Endogenous (industry specific) Variables that are believed to determine the level of NPAs.

Then, the equation would be;

$$
\begin{aligned}
\text { GNPA }_{i t}=\alpha & +\beta_{1} \text { GDPGR }_{\mathrm{t}}+\beta_{2} \text { PCNNP }_{\mathrm{t}}+\beta_{3} \mathrm{MCAP}_{\mathrm{t}}+\beta_{4} \mathrm{LR}_{\mathrm{t}}++\beta_{5} \mathrm{IIPGR}_{\mathrm{t}}+ \\
& +\beta_{6} \mathrm{INFLA}_{\mathrm{t}}+\beta_{7} \mathrm{SVGR}_{\mathrm{t}}+\beta_{8} \mathrm{ASSET}_{\mathrm{it}}+\beta_{9} \mathrm{CAR}_{\mathrm{it}}+\beta_{10} \mathrm{CDR}_{\mathrm{it}}+\beta_{11} \mathrm{COF}_{\mathrm{it}}+ \\
& +\beta_{12} \mathrm{ROA}_{\mathrm{it}}+\beta_{13} \mathrm{RUSUBR}_{\mathrm{it}}+\beta_{14} \mathrm{CREDGR}_{\mathrm{it}}+\beta_{15} \mathrm{PSL}_{\mathrm{it}}+\beta_{16} \mathrm{OER}_{\mathrm{it}}+ \\
& +\epsilon_{\mathrm{it}}
\end{aligned}
$$


Here, the explanatory variables $\mathrm{X}_{1} \ldots \ldots \mathrm{X}_{\mathrm{n}}$ are represented by the macro-economic variables such as GDP growth rate (GDPGR), inflation rate (INFLA), index of industrial production (IIPGR), savings growth rate (SVGR), growth rate in per capital income in NNP (PCNNP) and market capitalisation growth rate (MCAP) and endogenous variables such as bank assets (natural log) (ASSET), capital adequacy ratio (CAR), credit to deposit ratio, bank lending rates (LR), operating expenses to total assets (OER), ratio of priority sector loans to total loans (PSL), ratio of rural and semi urban branches to total bank branches and return on assets (ROA) that are supposed to determine the NPAs in the Indian context. While ' $\mathrm{i}$ ' represents the category of bank group, ' $t$ ' represents the year and $E_{\text {it }}$ represents the unexplained residual. This equation is estimated using the regression analysis considering gross NPA (GNPA) which is calculated as the ratio of gross non-performing assets to total advances and as regressand.

GDPGR is involved as a determinant in view of its all-pervading effect in the economy that may have a say in causing the NPAs. It controls for the macroeconomic conditions that owing to the business cycles in the economy have a significant role to play in causing defaults in loan repayments. It is also because of the reasoning that as the GDP increases the amount of NPAs decrease. INFLA is considered as a macroeconomic determinant as it is one of the aspects related to Indian economy which affects the banks overall performance especially the level of NPAs in the banking system. This is because when Reserve Bank of India (RBI) takes some steps related to interest rates to control inflation, the defaulters list also grows for the banks with the rising interest rates. Further, savings levels in an economy explain the savings propensity as well as the economic surpluses available which has a relation to the repayment capacity of the borrowers of the banking sector in general. In view of this, SGR is considered as a determinant. In addition, in a growing economy like India, Capital markets attract a whole lot of investors as well stimulate the capital formation in the country which has a bearing on the performance of the organised industrial sector. In view of this logic, Bombay Stock Exchange market capitalisation growth rate (MCAP) is considered as a determinant.

It is argued that Non Priority Sector is the prime contributor to the NPAs. To include this viewpoint in the study, bank assets (ASSET) is taken as control for whether the bigger banks are more vulnerable to the problem of NPAs than their smaller counterparts are. CAR was also considered as a determinant in view of the logic that the higher the capital of the banks 
the lower is the level of NPAs. It was also due to the fact that as capital base of the banks increases confidence of the bank also increases and gets reflected in their performance thus leading to effective recovery of bank loans and bringing down the level of NPAs. ROA is considered as an endogenous determinant because of the fact that profitability of banks would have a close relation with its NPAs.

It is obvious in general that the more profitable banks would have less NPAs. In order to capture the aggressiveness in lending activity of the banks which can lead to NPAs, credit to deposit ratio (CDR) is considered as an endogenous variable. Cost of Funds for the banks cause significant strategic decisions in the area of bank lending. In order to account this argument, cost of funds (COF) is also considered as a determinant. Growth in bank credit is also one of the factors that can determine the emergence of NPAs.

Table 4: Summary Statistics of the Variables

\begin{tabular}{|c|c|c|c|}
\hline Variable & Empirical Definition & Mean & Std. Dev. \\
\hline GNPA & Gross NPA to Total Advances & 6.797 & 4.710 \\
\hline ASSET & Bank Assets (natural log) & 12.432 & 1.091 \\
\hline CAR & $\begin{array}{l}\text { Capital Adequacy Ratio (Capital } \\
\text { to Risk Weighted Assets) }\end{array}$ & 12.487 & 1.275 \\
\hline CDR & Credit Deposit Ratio & 65.284 & 12.998 \\
\hline COF & Cost of Funds in percentage & 6.224 & 1.760 \\
\hline CREDGR & $\begin{array}{l}\text { Bank Credit Growth Rate (Growth in } \\
\text { real advances) }\end{array}$ & 20.780 & 10.962 \\
\hline GDPGR & $\begin{array}{l}\text { Growth Rate of real Gross Domestic } \\
\text { Product }\end{array}$ & 6.977 & 1.902 \\
\hline IIPGR & Index of Industrial Production & 6.808 & 2.155 \\
\hline INFLA & Inflation levels & 5.762 & 1.499 \\
\hline LR & Bank Lending Rates & 14.225 & 1.813 \\
\hline OER & Operating Expenses to Total Assets & 0.024 & 0.008 \\
\hline PCNNP & Per Capita Income at NNP & 5.323 & 2.303 \\
\hline PSL & Priority Sector Loans to Total Loans & 28.803 & 8.519 \\
\hline ROA & Return On Assets of banks & 0.941 & 1.604 \\
\hline RUSUBRA & $\begin{array}{l}\text { Ratio of Number of Rural and Semi- } \\
\text { Urban branches to Total bank branches }\end{array}$ & 0.395 & 0.267 \\
\hline SVGR & Savings Growth Rate & 16.094 & 7.317 \\
\hline
\end{tabular}

In view of this, credit growth rate (CREDGR) is considered as one of the determinants. In the area of bank lending the lending rates play a significant part. The cheaper the rates the Much of the operating expenses in the bank are believed to be towards employing the work force and related resources for credit deployment and recovery. Accordingly, operating expenses ratio is also considered as a variable. Proportion of rural and semi-urban 
Table 5: Determinants of NPAs

\begin{tabular}{|c|c|c|c|}
\hline Variables & Model-1 & Model-2 & Model-3 \\
\hline Constant & $\begin{array}{l}0.0000 \\
(39.899) * *\end{array}$ & $\begin{array}{l}0.0005 \\
(41.648) * *\end{array}$ & $\begin{array}{l}0.0000 \\
(42.482) * *\end{array}$ \\
\hline ASSET & $\begin{array}{l}0.0001 \\
(-2.214) * *\end{array}$ & $\begin{array}{l}0.0475 \\
(-1.975)^{*}\end{array}$ & $\begin{array}{l}0.0004 \\
(-2.127)^{* *}\end{array}$ \\
\hline CAR & $\begin{array}{l}0.6811 \\
(0.069)\end{array}$ & $\begin{array}{l}0.7787 \\
(-0.052)\end{array}$ & $\begin{array}{l}0.5983 \\
(0.074)\end{array}$ \\
\hline CDR & $\begin{array}{l}0.0000 \\
(-0.195)^{* *}\end{array}$ & $\begin{array}{l}0.0000 \\
(-0.154)^{* *}\end{array}$ & $\begin{array}{l}0.0000 \\
(-0.179)^{* *}\end{array}$ \\
\hline COF & $\begin{array}{l}0.0022 \\
(-0.833)^{* *}\end{array}$ & $\begin{array}{l}0.0000 \\
(-1.286)^{* *}\end{array}$ & $\begin{array}{l}0.0004 \\
(-1.279)^{* *}\end{array}$ \\
\hline CREDGR & $\begin{array}{l}0.7566 \\
(-0.007)\end{array}$ & $\begin{array}{l}0.2547 \\
(-0.018)\end{array}$ & $\begin{array}{l}0.1481 \\
(-0.036)\end{array}$ \\
\hline GDPGR & $\begin{array}{l}0.4074 \\
(0.550)\end{array}$ & $\begin{array}{l}0.2547 \\
(-0.018)\end{array}$ & $\begin{array}{l}0.2936 \\
(0.602)\end{array}$ \\
\hline IIPGR & -Na- & $\begin{array}{l}0.0486 \\
(-0.721)^{*}\end{array}$ & $-\mathrm{Na}-$ \\
\hline MCAP & $-\mathrm{Na}-$ & -Na- & $\begin{array}{l}0.0219 \\
(3.710)^{*}\end{array}$ \\
\hline INFLA & $\begin{array}{l}0.8574 \\
(-0.057)\end{array}$ & $\begin{array}{l}0.1425 \\
(0.870)\end{array}$ & $\begin{array}{l}0.2620 \\
(0.541)\end{array}$ \\
\hline LR & $\begin{array}{l}0.1397 \\
(0.654)\end{array}$ & $\begin{array}{l}0.1368 \\
(0.389)\end{array}$ & $\begin{array}{l}0.0950 \\
(0.621)\end{array}$ \\
\hline OER & $\begin{array}{l}0.0000 \\
(151.898)^{* *}\end{array}$ & $\begin{array}{l}0.0000 \\
(161.721)^{* *}\end{array}$ & $\begin{array}{l}0.0001 \\
(129.149)^{* *}\end{array}$ \\
\hline PCNNP & $\begin{array}{l}0.1586 \\
(-0.775)\end{array}$ & $\begin{array}{l}0.0993 \\
(-0.312)\end{array}$ & $\begin{array}{l}0.0206 \\
(-1.271) *\end{array}$ \\
\hline PSL & $\begin{array}{l}0.0264 \\
(-0.094)^{*}\end{array}$ & $\begin{array}{l}0.0958 \\
(-0.083)\end{array}$ & $\begin{array}{l}0.0212 \\
(-0.104)^{*}\end{array}$ \\
\hline ROA & $\begin{array}{l}0.0000 \\
(0.449)^{* *}\end{array}$ & $\begin{array}{l}0.0033 \\
(0.326)^{* *}\end{array}$ & $\begin{array}{l}0.0013 \\
(0.385)^{* *}\end{array}$ \\
\hline RUSUBRA & $\begin{array}{l}0.0914 \\
(6.220)\end{array}$ & $\begin{array}{l}0.1666 \\
(4.353)\end{array}$ & $\begin{array}{l}0.1039 \\
(5.096)\end{array}$ \\
\hline SVGR & $\begin{array}{l}0.1389 \\
(-0.053)\end{array}$ & $\begin{array}{l}0.2248 \\
(0.078)\end{array}$ & $\begin{array}{l}0.0166 \\
(-0.165)^{*}\end{array}$ \\
\hline SBDUMMY & $\begin{array}{l}0.7744 \\
(0.263)\end{array}$ & & \\
\hline NBDUMMY & $\begin{array}{l}0.3470 \\
(1.103)\end{array}$ & & \\
\hline OLDDUMMY & $\begin{array}{l}0.0341 \\
(-2.248)^{*}\end{array}$ & $-\mathrm{Na}-$ & $-\mathrm{Na}-$ \\
\hline NEWDUMMY & $\begin{array}{l}0.0001 \\
(-1.999)^{* *}\end{array}$ & -Na- & $-\mathrm{Na}-$ \\
\hline FDUMMY & $\begin{array}{l}0.0000 \\
(-3.374)^{* *}\end{array}$ & -Na- & $-\mathrm{Na}-$ \\
\hline R Square & 0.869 & 0.886 & 0.879 \\
\hline $\begin{array}{l}\text { Adjusted R } \\
\text { Square }\end{array}$ & 0.818 & 0.842 & 0.828 \\
\hline
\end{tabular}

Note: ** at $1 \%$ level of significance, * at less than 0.05 level of significance.

Source: Compiled from the results of the analysis by author. 
bank branches (RUSUBRA) has been considered as a determinant to examine whether the location of banks i.e, rural and semi-urban areas matter in causing NPAs in banking. The more is the recovery rate, the higher the rates the higher the defaults. In order to account this argument, Lending Rates are considered.

The more aggressive are the banks in their lending they may end up in pushing riskier loans and thereby end up in higher level of NPAs. However, there is a contention that as banks concentrates on credit management they may have developed expertise in managing the credit risk and hence may sometimes exhibit lower level of NPAs. Therefore the role of lending aggressiveness in causing increase in NPAs is still hazy. Ratio of priority sector lending to total bank lending (PSL) was included as a determinant in order to account for the argument that the Priority Sector Loans are responsible for the most number of defaults (Refer Figure-5).

Figure 5: Priority Sector Loans to Total Bank Credit in India

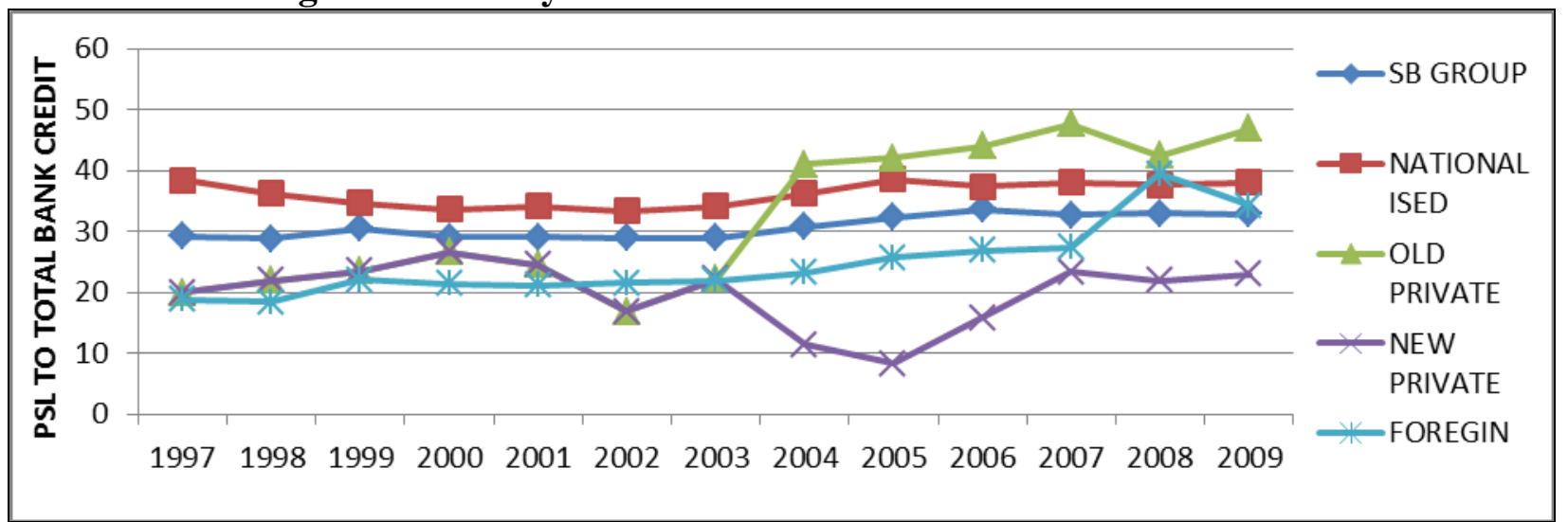

Source: Compiled by Author based on data from Reserve Bank of India publications.

Summary Statistics of the explanatory variables is furnished in Table 4 in the Annexures. Balanced panel data is used for estimation by employing the EViews tools for detailed analysis. Annual data on State Bank Group, Nationalised Banks Group, Old Private Banks Group, New Private Banks Group and Foreign Banks Group for the period from 1996-97 to 2008-09 is obtained from the robust data base of Reserve Bank of India (various issues of Statistical Tables Relating to Banks in India, the Report of Trend and Progress of Banking in India and the published annual audited accounts of individual banks).

The choice of the period is dictated by several considerations. The first is the availability of published data on the variables considered in the study. Secondly, the year 1996-97 marks the rigorous regime of the prudential norms as a result of the 'first generation' reforms programme initiated in 1991, so that it would be useful to examine the impact of various 
determinants and the behaviour of different banking sector in terms of NPAs through the initiation of the reform process. Further, the said period covers the significant period of postliberalisation in Indian banking.

\section{Results and Discussion}

Table 6: Nature and Strength of the Impact of Macroeconomic and Endogenous Determinants on NPAs

\begin{tabular}{|c|c|c|c|}
\hline $\begin{array}{l}\text { Explanatory } \\
\text { Variable }\end{array}$ & Model-1 & Model-2 & Model-3 \\
\hline ASSET & Negative and Significant & Negative and Significant & Negative and Significant \\
\hline CAR & Insignificant & Insignificant & Insignificant \\
\hline CDR & Negative and Significant & Negative and Significant & Negative and Significant \\
\hline $\mathrm{COF}$ & Negative and Significant & Negative and Significant & Negative and Significant \\
\hline CREDGR & Negative and Significant & Negative and Significant & Negative and Significant \\
\hline GDPGR & Not Significant & Insignificant & Insignificant \\
\hline IIPGR & ------------ & Negative and Significant & ------------- \\
\hline MCAP & ------------ & ------------ & Positive and Significant \\
\hline INFLA & Insignificant & Insignificant & Insignificant \\
\hline LR & Insignificant & Insignificant & Insignificant \\
\hline OER & Positive and Significant & Positive and Significant & Positive and Significant \\
\hline PCNNP & Insignificant & Negative and Significant & Negative and Significant \\
\hline PSL & Negative and Significant & Negative and Significant & Negative and Significant \\
\hline ROA & Positive and Significant & Positive and Significant & Positive and Significant \\
\hline RUSUBRA & Insignificant & Insignificant & Insignificant \\
\hline SVGR & Insignificant & Insignificant & Negative and Significant \\
\hline OLDDUMMY & Negative and Significant & $-\mathrm{Na}-$ & $-\mathrm{Na}-$ \\
\hline NEWDUMMY & Negative and Significant & $-\mathrm{Na}-$ & $-\mathrm{Na}-$ \\
\hline FDUMMY & Negative and Significant & -Na- & $-\mathrm{Na}-$ \\
\hline
\end{tabular}

Source: Compiled from the results of the analysis by author.

The result of the analysis is presented in Table 6 and the nature and strength of the impact of macroeconomic and endogenous determinants on NPAs are furnished in Table 6. GDP growth rate has no significance on the NPAs whereas as expected Per Capita Income has 
negative significance on NPAs. The coefficient of ASSET has turned out to be negative and very significant indicating that large banks may have better risk management procedures and technology which definitely allows them to finish up with lower levels of NPAs. It was also observed that CDR is negatively associated with bad loans signifying that higher the CDR the lower tends to be the level of NPAs.

As an alternative macro-economic variable, we employed the Index of Industrial Production (IIPGR) instead of GDPGR in Model-2. The results indicate that the coefficient on this variable is negatively significant as conjectured. Further, as another variant of the aforesaid specification, we introduce the market capitalisation ratio (MCAP) in Model-3 with a view to capture the transition from a bank based to market based financial system. The result shows that the coefficient is positively significant at 2 per cent level implying that transition to market orientation has impinged on the problem loans as the surpluses tend to move into the booming markets as investments and thereby affecting the repayments of bank loans.

As is theoretically well established when the ROA has increased, it is resulting in lesser amount of problem loans. Accordingly, the analysis has found that ROA is strongly associated with the NPAs negatively. Cost of Funds (COF) was found to be significantly associated with the NPAs negatively to evidence our viewpoint that as the cost of funds increase the banks tend to be very cautious and choosy in their lending thus leading to decrease in NPAs. Lending Rates have been found to be not so significant in affecting the NPAs contrary to the general perception. The rest of the explanatory variables exhibit theoretically expected relationships with NPAs and are self-explanatory as detailed in the columns 1, 2 and 3 of Table-6 which explains the Nature and Strength of the Impact of Endogenous determinants on NPAs.

The final subject of interest in this study was whether the NPAs are in any way affected by the ownership styles of the banks. This issue was investigated by introducing the ownership dummies (SBDUMMY for State Bank Group of banks, NBDUMMY for Nationalised Banks, OLDDUMMY for Old Private Banks, NEWDUMMY for New Private Banks and FDUMMY for Foreign Banks. The results summarized in Table-5 indicate that Private Banks (both Old and New) and Foreign Banks appear to manage their NPAs efficiently. State Bank Group and Nationalised Banks appear to lag behind their private counter parts in NPA management. 


\section{Policy Implications and Conclusion}

Several policy implications can be gleaned from this analysis. Favourable macroeconomic conditions facilitate in NPA management. First, as the banks grow in size, they tend to control the NPA owing to efficiency in their management. In this background there is a case for consolidation of banks in the public sector to reap this potential of efficiency in scale of operations. Larger banks have exhibited better credit risk management with lower NPA levels. Secondly, Priority Sector lending by banks is found to be not much significant in contributing for NPAs in contrast to the perception of some urban bankers that PSL cause NPAs. This supports the contention that branch expansion in rural and semi urban areas for extending priority sector credit is a viable proposition and there need not be aversion on this by the policy makers as well as the industry heads. Thirdly, Ownership of banks is an interesting issue that has been quite often debated. This study has established that private banks and foreign banks have advantages in terms of their efficiencies in better credit management in containing the NPAs which indicates that bank privatization can lead to better management of default risk.

The above findings infer that better credit risk management practices need to be taken up for bank lending. Adequate attention should be paid to those banks with low operating efficiency and low capitalisation as also to macroeconomic cycles that appear to be playing some role in NPA management. The state owned banks need to be toned up with adequate measures to sharpen their NPA management practices. These findings assume crucial importance in view of the significance.

Author information: Vighneswara Swamy is a professor at the IBS-Hyderabad, India. He may be contacted via E-mail: vighneswar@ibsindia.org 


\section{References}

Allan, F., and Gale, R., (2007). Understanding Financial Crisis, Oxford University Press, Oxford, United Kingdom.

Altman, E.L., Andrea Resti and Andrea Sironi, (2001). Analysing and Explaining Default Recovery Rates, A Report Submitted to the International Swaps \& Derivatives Association.

Ariff, M., (2012). The Origin of the Global Financial Crisis: An Alternative View, in M. Ariff, J. Farrar and A. Khalid (eds) Regulatory Failure and the Global Financial Crisis, Edward Elgar Publishing UK-USA.

Bama B., (2002). NPL Securitisation in China - Anatomy of the deal, Structured Product Group, ICICI Research Bangalore, 2002.

Barseghyan, L., (2004). Non-performing Loans, Prospective Bailouts, and Japan's Slowdown, Cornell University, New York, NY, USA.

Beck T.A, Demirguc-Kunt and R. Levine (2005). Bank concentration and Fragility: Impact and Mechanics, NBER Working Papers 11500, National Bureau of Economic Research Inc.

Berger, A.N., and R De Young (1995). Problem loans and cost efficiency in commercial banks, Journal of Banking \& Finance 21: 849-870.

Bhattacharya, H., (2001). Banking Strategy, Credit Appraisal \& Lending Decisions, Oxford University Press, New Delhi.

Bodla B.S., and Richa Verma (2006). Determinants of Profitability of Banks in India: A Multivariate Analysis, Journal of Services Research, Vol. 6 (2: (October 2006 March 2007).

Chen, J., (2004). Non-performing Loan Securitization in the People's Republic of China, Stanford University, Palo Alto, CA, USA.

Chen, C.R., T.L. Steiner and A.M. Whyte (1998). Risk-taking behavior and management ownership in depository institutions, The Journal of Financial Research 21: 1-16.

Das, Abhiman, (1999). Efficiency of Public Sector banks: An application of Data Envelopment Model, Prajnan Vol. 28 (2, September 1999).

Das A., and Ghosh S., (2003). Determinants of Credit Risk, Paper presented at the Conference on Money, Role and Investment held at Nottingham Treat University in Nov 2003.

Dermiguc-Kunt, A., and E. Detragiache (2000). Monitoring banking Sector Fragility: A Multivariate Logit Approach, World Bank Economic Review, Vol. 14 (2): 287307.

Devakula, Pridiyathorn (2001). Monetary policy in Thailand: current challenges and Prospects, APFA 2001 Conference, Bangkok, 24 July 2001.

Ernst \& Young (2001). Non-Performing Loan Report: Asia 2002, Ernst \& Young, New York.

Fernandez de Lis S, J Martinez-Pages and Surina, (2000). Credit Growth, Problem Loans, and Credit Risk Provisioning in Spain, Working Paper No. 0018, Banco de Espana

Goldsmith, R. W (1969), Financial Structure and Development, New Haven, CT: Yale University Press.

Hu, Jin-Li, Yang Li and Chiu, Yung-Ho (2002). Ownership and Non-performing Loans: Evidence from Taiwanese Banks, Proceedings of International Conference, National Taiwan University.

Huang, Yiping, (1999). Dealing with Bad Loans of the Chinese Banks, China Update 1999 Conference Papers, November, National Centre for Development Studies.

IMF (2009). Global Financial Stability Report- Responding to the Financial Crisis and 
Measuring Systemic Risks', World Economic and Financial Surveys, International Monetary Fund, Washington DC, April 2009.

Kang, Moon-Soo (2001). Financial Restructuring in Korea, Korea Development Institute October 2001.

Kwan, S., and R. Eisenbis (1997). Bank Risk, Capitalization and Operating Efficiency, Journal of Financial Services Research 12: 117-131.

Levine, R., (2004). Finance and Growth: Theory, Evidence \& Mechanism', edited by Aghion, P and Durlauf, S. (eds), Handbook of Economic Growth, Amsterdam: NorthHolland, pp.81, in Reforming Corporate Governance in Southeast Asia, by Khai Leong Ho (2005), published by Institute of Southeast Asian Studies.

Lis, S.F. de, J.M. Pages, and J. Saurina (2000). Credit Growth, Problem Loans and Credit Risk Provisioning in Spain Banco de España - Servicio de Estudios, Documento de Trabajo no. 0018.

Lu, Ding, Thangavelu, Shandre, M., and Qing, Hu, (2001). The Link between Bank Behavior and Non-performing Loans in China, Working Paper No. 0108, National University of Singapore.

Rajaraman, Bhaumik and Bhatia (1999). NPA variations across Indian Commercial banks, some findings, Economic and Political Weekly Vol. 37 (3-4): 16-23.

Rajaraman Indira and Vasishstha (2002). Non Performing Loans of Public Sector banks Some Panel Results, Economic and Political Weekly (February 2002).

Ranjan, Rajiv, and Sarat Chandra Dhal (2003). Non-Performing Loans and Terms of Credit of Public Sector Banks in India: An Empirical Assessment, Reserve Bank of India Occasional Papers, Vol. 24 (3): Winter 2003.

Sergio, M., (1996). Non-performing bank loans: Cyclical patterns and Sectoral risk, Review of Economic Conditions in Italy, Rome: Jan-Jun 1996, Issue 1.

Singh, C., (2005). Financial sector reforms and state of Indian economy, Indian Journal of Economics \& Business Vol. 4 (1): 88-133.

Sprayregen, J., Friedland, J., Miller, N., and Li, C., (2004). Non-performing loans in China: a potential win-win opportunity for foreign investors and China's economy, Global Restructuring \& Insolvency Review, pp. 38-9.

Wahlen, J., (1994). The nature of information in commercial bank loan loss disclosures, The Accounting Review 69: 455-478. 